\title{
Utilization of Z-6040 Organosilane as a Coupling Agent to Improve the Adhesion of Epoxy Resins to Waxy Biological Tissues
}

\author{
Joseph Mowery and Gary Bauchan
}

US Department of Agriculture, Agricultural Research Service, Beltsville, Maryland, United States

A commonly encountered obstacle when embedding waxy biological tissues for transmission electron microscopy (TEM), especially plant or insect tissue, is the tendency of the resin to detach from the tissue during ultramicrotomy. The inclusion of 1\% Z-6040 organosilane (3-glycidoxypropyltrimethox-silane) during the dehydration process, functions as a coupling agent to enhance adhesion of the resin to the tissue. The Z-6040 organosilane molecule contains a trimethoxysilyl group on one end which reacts with the hydroxyl groups on the surface of the tissue and an epoxy group on the opposite end which crosslinks with the epoxy resin, thereby acting as a coupling agent between the resin and tissue [1].

The use of Z-6040 for TEM was originally reported by Sway and Klinger in 1988 for embedding thin metal films and later adapted by Lindley in 1992 for embedding biological specimens in LR White acrylic resin $[2,3]$. While LR White is a widely-used resin for immunolabeling, it possesses several disadvantages including the requirement to polymerize the resin in gelatin capsule molds in the absence of oxygen, limiting the ability to quickly orient tissue in the molds and hindering productivity when examining large quantities of samples. LR White is also prone to cause tissue shrinkage, premature polymerization and chipping during trimming. For morphological studies, Epon-type epoxy resin has minimal drawbacks, tissue can be efficiently oriented and embedded in flat molds and the resin has excellent trimming and sectioning properties. Here we report on the use of Z-6040 for embedding waxy biological tissue in Epontype epoxy resin and examine the resin adhesion to eggs of the squash bug (Anasa tristis) and leaves of sweet orange (Citrus sinensis).

A small cut was made on one end of the squash bug egg to facilitate infiltration and a $1 \mathrm{~mm}$ biopsy punch was used to excise the leaf tissue, then the samples were fixed and microwave processed as previously described with the addition of 1\% Z-6040 (Electron Microscopy Sciences, Hatfield, PA) added to all the dehydration steps [4]. For comparison, samples were also embedded without Z-6040, and with 1\%, 2\%, and 4\% Z-6040 added directly into all the resin steps. All samples were embedded in a hard formulation of LX-112 resin with BDMA accelerator and oven polymerized at $60^{\circ} \mathrm{C}$ for 24 hours. Sections were cut to $60 \mathrm{~nm}$ with a Diatome $35^{\circ}$ diamond knife using a Leica UC7 ultramicrotome, then stained with $4 \%$ lead citrate and imaged at $80 \mathrm{kV}$ with a Hitachi 7700 TEM.

As expected, the samples embedded without Z-6040 were observed to have small gaps along the perimeter of the cuticle where the resin had separated from the tissue (Figure 1). This separation can be especially problematic when studying fine details on the outermost surface of the cuticle, such as the microplates of flat mites (Brevipalpus spp.). Samples that were primed with 1\% Z-6040 in the dehydration stage resisted section pull-out during ultramicrotomy and showed no signs of resin separation (Figure 1). Samples that were embedded with Z-6040 added directly to the epoxy resin, showed signs of poor polymerization as the concentration of Z-6040 increased respectively. Thus, the use of Z-6040 throughout the dehydration stage is an effective method for improving the adhesion of Epon-type epoxy resin to waxy biological tissue. 

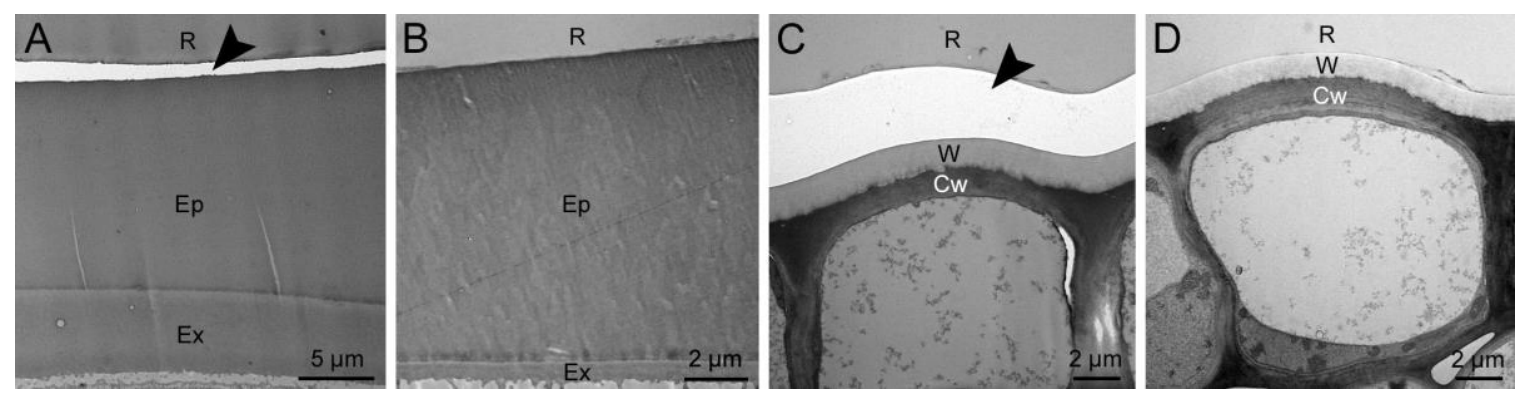

Figure 1. Ultrastructure of the cuticle of the squash bug egg $(\mathrm{A}, \mathrm{B})$, and the epidermis of citrus leaves $(\mathrm{C}$, D), embedded without the addition of Z-6040 (A, C), and with the addition of 1\% Z-6040 (B, C), with arrowheads pointing to the area where the resin has separated from the tissue. Ep: epicuticle; Ex: exocuticle; R: epoxy resin; $\mathrm{Cw}$ : cell wall; $\mathrm{W}$ : wax layer.

\section{References}

[1] A. Konakanchi, R. Alla, V Guduri. Trends Biomater. Artif. Organs, 31 (2017) p. 109-113

[2] P. Swab, R. Klinger. Mat. Res. Soc. Proc. 11 (1988) p. 229-234.

[3] V.A. Lindley, Microsc Res Techniq 21 (1992) p. 355-360

[4] J. Mowery and G. Bauchan Microsc. Microanal. 24 (2018) p. 1202-1203 